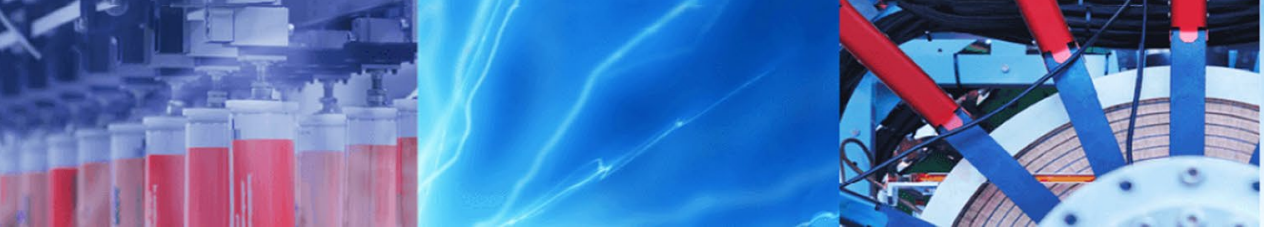

Research Article

\title{
Characteristics of co-precipitation synthesized cobalt nanoferrites and their potential in industrial wastewater treatment
}

\author{
Mohammed A. Albalah ${ }^{1}$ Yousef A. Alsabah ${ }^{2,3,4} \cdot$ Damra E. Mustafa $^{1}$
}

Received: 19 September 2019 / Accepted: 24 March 2020 / Published online: 3 April 2020

(c) Springer Nature Switzerland AG 2020

\begin{abstract}
Cobalt-nanoferrite as a magnetic separable material has drawn the attention of researchers due to its unique properties, significant applications and high potentiality in wastewater treatment. In this study, the cobalt nanoferrite was synthesized by chemical co-precipitation method at different annealing temperatures and characterized by X-ray diffraction, scanning electronic microscopy, energy dispersive X-ray, Fourier transform infrared spectroscopy and UV-visible spectroscopy. Then the synthesized nanoferrite was assessed and used for the treatment of tannery wastewater. The characterizations confirmed the formation of nanoferrites with size between 15 and $23 \mathrm{~nm}$. The average particle size increased with increase of annealing temperatures. Typical values for tannery wastewater treatment efficiency for chromium, total dissolved solids, biochemical oxygen demand and chemical oxygen demand were 23.75, 90.83, 52.72 and $48.07 \%$ respectively. Thus, the treatment by nanoferrites appears a promising and effective method for the removal of contaminants.
\end{abstract}

Keywords Cobalt nanoferrite $\cdot$ Tannery wastewater $\cdot$ Chromium $\cdot$ TDS $\cdot$ BOD $\cdot$ COD

\section{Introduction}

Chemical contaminants in industrial wastewater have serious effects on health and ecological environment especially in the industrial areas where large quantities of discharges are daily generated. These contaminants include heavy metals, inorganic compounds, organic materials, and other complex compounds [1-3].

The treatment of wastewater by nanoparticles is a fascinating area of research and gaining global momentum due to environmental friendly and cost-effective materials involved in the process and thus offers great opportunities to the wastewater treatment techniques [4]. In particular, nanoparticles are characterized by many unique properties such as small size, large specific surface area, high dispersion, selectivity and easily modifiable surface by chemical methods [5]. Consequently, the nanoparticles have been used to remove toxic substances such as lead [5], arsenic [6, 7], chromium [6], cadmium [8], nickel [9] and mercury [10].

Among these toxic heavy metals, chromium has adverse impacts on human health such as allergies, hyper pigmentation, skin cancer, neurological effect, hypertension and cardiovascular disease [11]. Chromium is considered as a main tannery material and highly dispersible pollutant. Therefore, researchers focus on developing and exploiting the nanomaterials as alternatives to known treatment agents. In particular, titanium oxide [12] and nanoferrite materials $[13,14]$ have been used. Among these, nanoferrites are the most studied, not only because of their ability to remove heavy metals but also due to their other potential applications in many fields [15]. Nanoferrites

Damra E. Mustafa, damrj@bahri.edu.sd| 1 Department of Chemistry and Industrial Science, College of Applied and Industrial Sciences, University of Bahri, Khartoum, Sudan. ${ }^{2}$ Department of Physics, Faculty of Science and Technology, Al Neelain University, Khartoum, Sudan. ${ }^{3}$ Research Chair in Laser Diagnosis of Cancers, College of Science, King Saud University, Riyadh, Kingdom of Saudi Arabia. ${ }^{4}$ Department of Physics, Faculty of Education and Applied Sciences, Hajjah University, Hajjah, Yemen. 
are characterized by their high electrical impedance, high permeation, stability and longevity. Moreover, nanoferrite precursors are cost-effective and less hazardous [14]. The nanoferrites are classified into three main types depending on their structure namely spinel, garnet and hexagonal ferrites [16]. The spinel nanoferrite represents a wide group of oxides, with the general chemical formula of $\mathrm{MFe}_{2} \mathrm{O}_{4}$, where $\mathrm{M}$ represents $\mathrm{Fe}, \mathrm{Mn}, \mathrm{Co}, \mathrm{Mg}, \mathrm{Zn}, \mathrm{Ni}$, etc. [17]. The spinel nanoferrites have been studied by several researchers $[18,19]$. Different transition metals have been involved such as $\mathrm{NiFe}_{2} \mathrm{O}_{4}$ [20], $\mathrm{CoFe}_{2} \mathrm{O}_{4}$ [20-22], $\mathrm{Zn}_{x} \mathrm{Ni}_{1-\mathrm{x}} \mathrm{Fe}_{2} \mathrm{O}_{4}$ [23], $\mathrm{ZnFe}_{2} \mathrm{O}_{4}[24,25]$, and $\mathrm{MgFe}_{2} \mathrm{O}_{4}[26,27]$.

The spinel cobalt nanoferrites have unique properties such as magnetization, magnetic crystalline, high coercivity, moderate saturation magnetization, large magnetostrictive coefficient, chemical stability and mechanical hardness [28]. Therefore several useful applications have been associated with spinel cobalt ferrites $\left(\mathrm{CoFe}_{2} \mathrm{O}_{4}\right)$ such as adsorbent for the treatment of different environmental pollutants [29]. Interestingly, it has been noted that slight modifications in the formula of nanoferrite and concentrations of reactants can result in important changes in the geometry of this compounds and hence the role and function of these nanomaterials [30]. For example, UV-visible diffuse reflectance spectra and band gap energy of spinel $\mathrm{Mg}_{1-y} \mathrm{Ni}_{y} \mathrm{Fe}_{2} \mathrm{O}_{4}(0.0 \leq \mathrm{y} \leq 1.0)$ nanoparticles have been found to increase from 2.1 to $2.6 \mathrm{eV}$ with increasing $\mathrm{Ni}^{2+}$ ratio [31].

As very limited works have been made to study the size effect and application of nanoferrites, hence the aims of the present work were to synthesize and investigate spinel cobalt ferrite $\left(\mathrm{CoFe}_{2} \mathrm{O}_{4}\right)$ nanoparticles with different sizes for the treatment of tannery wastewater with emphasis on removal of chromium. Thus the nanoparticles were synthesized using co-precipitation method and annealed at 300,500 and $900^{\circ} \mathrm{C}$. The obtained nanoparticles were then characterized by X-ray diffraction pattern (XRD), scanning electron microscopy (SEM), energy dispersive $X$-ray (EDX), Fourier-transform infrared spectroscopy (FTIR) and ultraviolet visible spectrometer (UV-VIS). The obtained spinel ferrite nanoparticles were employed for the removal of chromium and other contaminants from tannery wastewater. The effect of the nanoparticle amount, $\mathrm{pH}$ and concentration on the removal process were also investigated.

\section{Experimental}

\subsection{Chemicals}

Cobalt(II) nitrate $\geq 98 \%$, iron(III) nitrate $\geq 98 \%$, and sodium hydroxide were purchased from SD Fine-Chem Limited, Mumbai, India. All the chemicals used in this study were of analytical reagent grade and were used without further purification.

\subsection{Tannery wastewater sample}

The tannery wastewater samples were collected from the tannery discharge tanks in Sajjana, central of Khartoum city, Sudan. The tannery in this zone is producing semifinished tanned leathers. The high-density $600 \mathrm{ml}$-liter PVC bottles were used to collect the samples after rinsing with distilled water and the wastewater.

\subsection{Synthesis and annealing}

The chemical co-precipitation method was used to synthesize the cobalt spinel nanoferrites by dissolving $4.04 \mathrm{~g}$ of $\mathrm{Fe}\left(\mathrm{NO}_{3}\right)_{3} \cdot \mathrm{H}_{2} \mathrm{O}$ and $1.455 \mathrm{~g}$ of $\mathrm{Co}\left(\mathrm{NO}_{3}\right)_{2} \cdot 6 \mathrm{H}_{2} \mathrm{O}$ in $200 \mathrm{ml}$ of water [32]. The quantity of each metal precursor was adjusted so that the ratio of $\mathrm{Co}$ to $\mathrm{Fe}$ in the mixture to be 1:2. The mixture was stirred for ten minutes, while constantly mentoring the $\mathrm{pH}$ by drop wise addition of $\mathrm{NaOH}$ solution ( $3 \mathrm{M})$. Then the mixture was allowed to cool to room temperature and stirred for twenty minutes. After that, the mixture was heated again to $80^{\circ} \mathrm{C}$ and stirred for one hour and allowed to form a precipitate product. The product was allowed to cool to room temperature, washed twice with distilled water and ethanol and dried in hot air oven for $4 \mathrm{~h}$ at $130^{\circ} \mathrm{C}$. The acquired substance was then grinded in agate mortar and pestle into a powder and annealed at 300,500 and $900{ }^{\circ} \mathrm{C}$ for three hours in a furnace.

\subsection{Characterization}

The crystalline phases and unit cell parameters of the powders were determined by XRD, using a Shimadzu 7000 $\mathrm{X}$-ray diffractometer with $1.5406 \AA$ wavelength $\mathrm{Cu}-\mathrm{k}_{\alpha}$ radiation and a nickel filter operating at $40 \mathrm{kV} / 40 \mathrm{~mA}$. Data were collected for a $2 \theta$ range of $20^{\circ}-80^{\circ}$ at a step size for $0.02^{\circ}$ and $5 \mathrm{~s}$ count-times. The Maud program was used for XRD analysis, with the Rietveld refinement method. The crystalline size $(D)$ was calculated by Scherer's equation [33]:

$D=\frac{\mathrm{k} \lambda}{\beta \cos \theta}$

where $D$ is the crystalline size $(\mathrm{nm}), K$ is the Scherer constant with a value of $0.94, \lambda$ is the $X$-ray wavelength in $\mathrm{nm}$, for $\mathrm{CuK}_{\alpha}$ radiation it is $0.1054 \AA$, $\theta$ is the Bragg diffraction angle, and $\beta$ is the full width at half maximum (FWHM) of the XRD peak appearing at the diffraction angle. The morphology of the powder was investigated by SEM (Tescan Vega3), and the composition was determined by EDX [34]. 
The infrared spectra (wavelength range: $280-4000 \mathrm{~cm}^{-1}$ ) were recorded using an FTIR spectrometer (SHIMADZU model 8400S) [35]. A FTIR spectroscopy collected by $\mathrm{KBr}$ pellet method, the material mixed with $\mathrm{KBr}$ in the ratio of 1:100. The UV-VIS absorption spectra were obtained using a U-VIS spectrophotometer (Shimadzu, UV-2400) in the wavelength range of $200-800 \mathrm{~nm}$ to investigate the optical property of material. All samples used for characterization were prepared by dissolving in ethanol.

\subsection{Treatment by spinel nanoparticle}

In order to estimate the optimum conditions and effect of interferences in the tannery wastewater caused by other materials or pollutants, initially, the nanoparticle was examined by using prepared chromium solution under different nanoferrites dosage, $\mathrm{pH}$ and chromium concentrations. In a typical treatment experiment, a mixture of $50 \mathrm{ml}$ was obtained by mixing nanoparticle and chromium or wastewater solutions. The mixture was then agitated in a mechanical shaker. Nanoparticle amount was varied from $0.10,0.15,0.20,0.25$ and $0.30 \mathrm{~g}$. The $\mathrm{pH}$ of treatment mixture was adjusted by addition of $\mathrm{HCl}(0.1 \mathrm{M})$ or $\mathrm{NaOH}$ $(0.1 \mathrm{M})$ to 3,5 and 7 . The initial chromium amounts were obtained by taking $10,20,30,40$ and $50 \mathrm{ml}$ from a standard chromium solution (1 $\mathrm{mM}$ ).

The concentration of chromium before and after treatment was estimated by atomic absorption spectrophotometer (Perkin Elmer Analyst 200 model). The percent of chromium removal efficiency was evaluated using the following equation:

Removal efficiency $(R)(\%)=\frac{C_{o}-C_{e}}{C_{o}} \times 100$

where $C_{o}$ is initial concentration of chromium before treatment $\mathrm{mg} / \mathrm{l}, \mathrm{C}_{\mathrm{e}}$ is final concentration of chromium after treatment $\mathrm{mg} / \mathrm{l}$.

Beside chromium treatment by nanoferrite, other physicochemical parameters, such as total dissolved solids (TDS), chemical oxygen demand (COD), and biochemical oxygen demand (BOD) were also investigated. The investigations of these parameters were performed according to known standard procedures [18]. Specifically, TDS was measured by transferring of the sample to a weighed evaporating dish and evaporated to dryness by heating at $180^{\circ} \mathrm{C}$. TDS was calculated by taking the weight of residue to volume of the sample. COD was estimated by oxidizing using excess dichromate and then titrating with ferroin indicator. BOD was obtained by determining the dissolved oxygen concentrations in the sample before and after an incubation period.

\section{Result and discussion}

\subsection{Synthesis and characterization of the nanoferrites}

The co-precipitation method is a promising and reliable method for the synthesis of nanomagnetic particles such as cobalt nanoferrite. The obtained materials were black powder and showed attraction to magnet. Interestingly, the one annealed at $900^{\circ} \mathrm{C}$ showed the higher attraction to the magnet, therefore it was used for the treatments. These characteristics of the synthesized materials indicate formation of nanoferrites [36].

The synthesized products were characterized by XRD and the results are displayed in Fig. 1. The peaks are located in the $2 \theta$ range of $20^{\circ}-80^{\circ}$ and all samples exhibited a cubic structure with an $\mathrm{Fd}-3 \mathrm{~m}$ space group [37]. The lattice parameters $a$ for the samples were found to increase with increasing annealing temperature. The lattice parameters were $8.365627,8.372012$ and $8.395217 \AA$, for annealing temperatures of 300,500 and $900^{\circ} \mathrm{C}$ respectively. Table 1 presents the XRD results. The nanoparticle crystallite sizes as calculated from the $X$-ray line broadening and using the diffraction peaks given by the Debye-Scherer formula were found to be 15, 18, and, $23 \mathrm{~nm}$. The lattice parameter and crystallite size was found to increase with increasing annealing temperature, as depicted in Fig. 2. Table 2 lists the atomic coordination and occupancy of the samples. The increase of crystallite size with increasing annealing temperature may be due to grain growth taking place and greater chances of agglomeration at elevated temperatures.

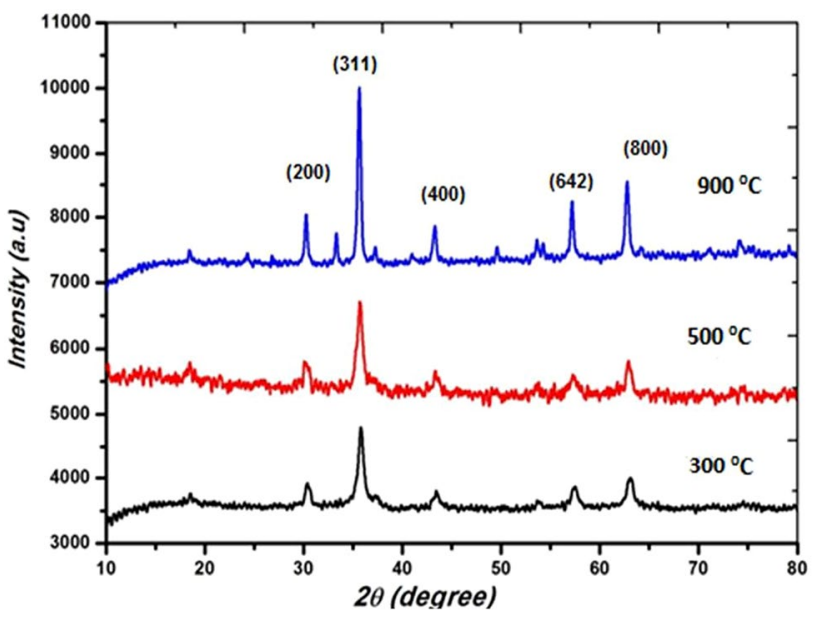

Fig. 1 XRD characterization of $\mathrm{CoFe}_{2} \mathrm{O}_{4}$ nanoparticles annealed at 300,500 and $900^{\circ} \mathrm{C}$ 
Table 1 XRD Analysis of the spinel nanoparticles annealed at 300,500 and $900^{\circ} \mathrm{C}$

\begin{tabular}{lllllll}
\hline $\mathrm{CoFe}_{2} \mathrm{O}_{4}$ at & $\begin{array}{l}\text { Crystallite } \\
\text { size }(\mathrm{nm})\end{array}$ & Lattice constant (Å) & Volume $\mathrm{nm}^{3}$ & Space groups & Sigma & $\begin{array}{l}\text { Weighted } \\
\text { R-factor }\left(\mathrm{R}_{\mathrm{w}}\right) \\
(\%)\end{array}$ \\
\hline $300^{\circ} \mathrm{C}$ & 15 & 8.365627 & 585.45766 & $\mathrm{Fd}-3 \mathrm{~m} \mathrm{(227)}$ & 1.5023453 & 2.5053240 \\
$500{ }^{\circ} \mathrm{C}$ & 18 & 8.372012 & 586.79922 & $\mathrm{Fd}-3 \mathrm{~m} \mathrm{(227)}$ & 1.2143844 & 7.4379373 \\
$900{ }^{\circ} \mathrm{C}$ & 23 & 8.395217 & 591.69211 & $\mathrm{Fd}-3 \mathrm{~m} \mathrm{(227)}$ & 1.6325004 & 2.7997284 \\
\hline
\end{tabular}
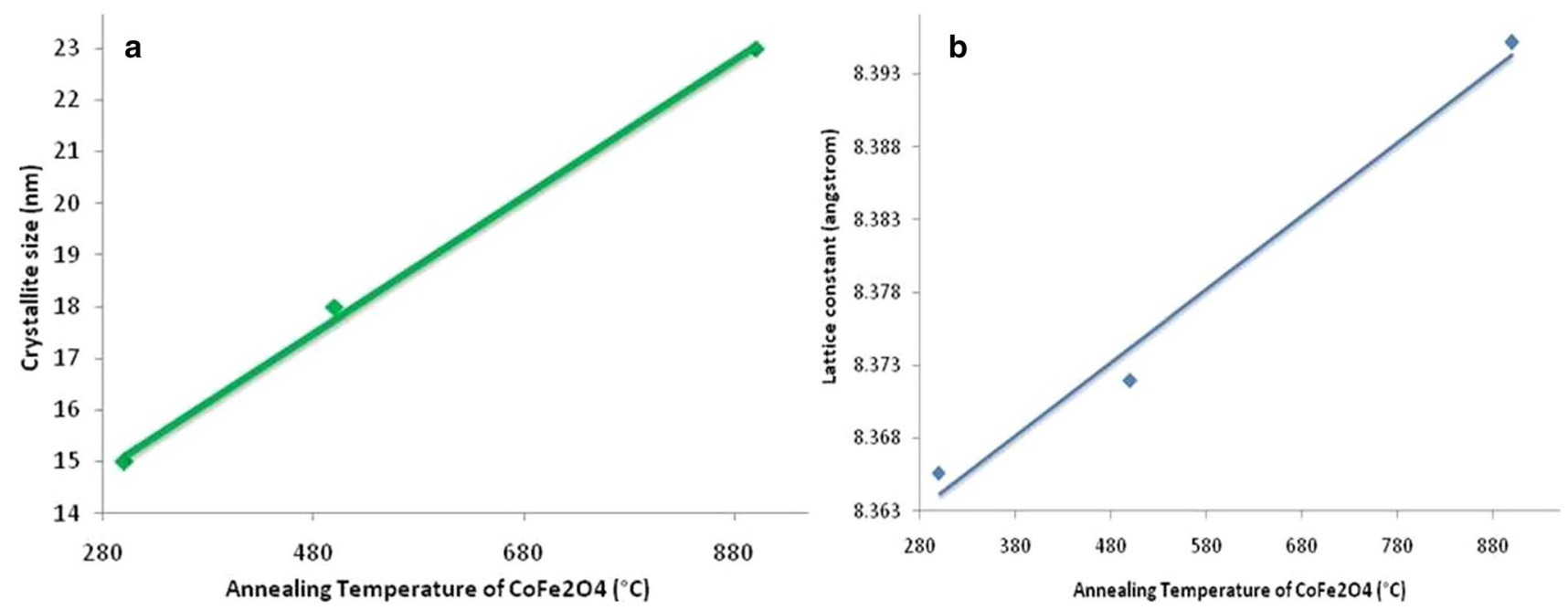

Fig. $2 \mathrm{CoFe}_{2} \mathrm{O}_{4}$ nanoparticles a crystallite size vs annealing temperature, $\mathbf{b}$ Lattice parameter versus the annealing temperature

The SEM images (Fig. 3a-c), show that the samples consist of aggregated materials at all annealing temperatures and smaller crystallites are closely arranged together. The SEM images depict morphologies with different shapes, size and high particle surface roughness. The samples exhibit a compact arrangement of homogeneous nanoparticles, which is observed in particles that are almost uniform in size. Obviously the morphologies, size and magnetic properties of the synthesized nanoferrites change with the annealing temperature.

Figure $3 \mathrm{~d}$ presents the energy dispersive $\mathrm{X}$-ray EDX of the $\mathrm{CoFe}_{2} \mathrm{O}_{4}$ nanoparticle annealed at $300^{\circ} \mathrm{C}$, it reveals the presence of elements, such as cobalt, iron, and oxygen, without any additional impurities, with a ratio of 1:2 for the Co:Fe ions.

Figure 4 displays the FTIR spectra of the samples. The absorbance peaks around $416-458 \mathrm{~cm}^{-1}$ are assigned to the $\mathrm{Fe}-\mathrm{O}$ and $\mathrm{Co}-\mathrm{O}$ bond-stretching vibrations [29]. The peak appearing at $584 \mathrm{~cm}^{-1}$ is attributed to $\mathrm{Fe}^{3+}-\mathrm{O}^{2-}$. The appearance of absorption bands in the range $400-600 \mathrm{~cm}^{-1}$ reveal the formation of single phase spinel structure having tetrahedral and octahedral sites [38]. Thus, FTIR spectra exhibited main absorption bands, thereby confirming the formation of spinel $\mathrm{CoFe}_{2} \mathrm{O}_{4}$ nanoparticle.
The absorbance spectra were recorded for obtaining the absorption edge values of the $\mathrm{CoFe}_{2} \mathrm{O}_{4}$ nanoferrites, as shown in Fig. 5. The maximum absorption for the samples was displayed in the ultraviolet region at 250 and $260 \mathrm{~nm}$ for the $\mathrm{CoFe}_{2} \mathrm{O}_{4}$ nanoferrites annealed at 300 and $900{ }^{\circ} \mathrm{C}$, respectively. These bands developed from the absorption of nanoferrites, which in agreement with previous report [39]. The band gap energy, $E_{g}=1240 / \lambda$, of the samples was calculated as reported before by Alsabah et al. from the absorption edge as 4.97 and $4.78 \mathrm{eV}$ for the nanoferrite annealed at 300 and $900{ }^{\circ} \mathrm{C}$, respectively [40]. As the values of band gap inversely related to the size of nanoparticle, thus confirmed size difference of the synthesized nanoferrites.

\subsection{Treatment by $\mathrm{CoFe}_{2} \mathrm{O}_{4}$}

\subsubsection{Treatment conditions}

The nanoferrite with size $23 \mathrm{~nm}$ was chosen for the treatment due to better attraction to magnet, which allowed convenient separation from the treated mixture. In order to optimize the removal of chromium by $\mathrm{CoFe}_{2} \mathrm{O}_{4}$ nanoparticle, several attempts were conducted to assign the appropriate treatment conditions as follows: 
Table 2 The atomic coordination and occupancy of spinel nanoparticles annealed at 300,500 and $900^{\circ} \mathrm{C}$

\begin{tabular}{|c|c|c|c|c|}
\hline Cation/anion & Coordinates & $300^{\circ} \mathrm{C}$ & $500^{\circ} \mathrm{C}$ & $900{ }^{\circ} \mathrm{C}$ \\
\hline \multirow[t]{4}{*}{$\mathrm{Fe}_{1}^{+2}$} & $X$ & 0.125 & 0.125 & 0.125 \\
\hline & $\mathrm{Y}$ & 0.125 & 0.125 & 0.125 \\
\hline & Z & 0.125 & 0.125 & 0.125 \\
\hline & OCC & 0.543 & 0.543 & 0.543 \\
\hline \multirow[t]{4}{*}{$\mathrm{Fe}_{2}^{+2}$} & & 0.5 & 0.5 & 0.5 \\
\hline & & 0.5 & 0.5 & 0.5 \\
\hline & & 0.5 & 0.5 & 0.5 \\
\hline & OCC & 0.229 & 0.229 & 0.229 \\
\hline \multirow[t]{4}{*}{$\mathrm{Co}_{1}^{+2}$} & $x$ & 0.125 & 0.125 & 0.125 \\
\hline & $\mathrm{Y}$ & 0.125 & 0.125 & 0.125 \\
\hline & Z & 0.125 & 0.125 & 0.125 \\
\hline & OCC & 0.457 & 0.457 & 0.457 \\
\hline \multirow[t]{4}{*}{$\mathrm{Co}_{2}^{+2}$} & $X$ & 0.50 & 0.50 & 0.50 \\
\hline & $\mathrm{Y}$ & 0.50 & 0.50 & 0.50 \\
\hline & Z & 0.50 & 0.50 & 0.50 \\
\hline & OCC & 0.271 & 0.271 & 0.271 \\
\hline \multirow[t]{4}{*}{$\mathrm{CO}_{3}^{+2}$} & $X$ & 0.5 & 0.5 & 0.5 \\
\hline & $\mathrm{Y}$ & 0.5 & 0.5 & 0.5 \\
\hline & Z & 0.5 & 0.5 & 0.5 \\
\hline & OCC & 0.5 & 0.5 & 0.5 \\
\hline \multirow[t]{4}{*}{$\mathrm{O}_{1}^{-2}$} & $x$ & 0.2629 & 0.23890 & 0.25532 \\
\hline & $\mathrm{Y}$ & 0.2629 & 0.23890 & 0.25532 \\
\hline & Z & 0.2629 & 0.23890 & 0.25532 \\
\hline & OCC & 1 & 1 & 1 \\
\hline
\end{tabular}

1. Nanoparticle dose effect: Fig. 6a presents the effect of changing $\mathrm{CoFe}_{2} \mathrm{O}_{4}$ amounts on the removal of chromium(VI). Obviously, the efficiency of $\mathrm{CoFe}_{2} \mathrm{O}_{4}$ was found to increase with increasing the amount of nanoparticles. The highest removal percentage was found to be $75.45 \%$, which was in agreement to pervious report [41,42]. This result was anticipated as large nanoparticle amount provide more surface area.

2. Effect of pH: The results are shown in Fig. $6 \mathrm{~b}$, which indicate that the maximum removal percentage of $\mathrm{Cr}(\mathrm{VI})$ occurred at $\mathrm{pH} 3$ (64.67\%) and the $\mathrm{pH}$ value of chromium solutions during the nanoferrite treatment appeared as a critical parameter. Similar observation has been reported [43]. Therefore, the $\mathrm{pH}$ value of 3 was chosen as the optimal $\mathrm{pH}$ for the treatment of $\mathrm{Cr}(\mathrm{VI})$. The effect of $\mathrm{pH}$ of solution on the treatment is probably due to affecting adsorption of $\mathrm{Cr}(\mathrm{VI})$ i.e. in acidic medium, $\mathrm{Cr}(\mathrm{VI})$ exits in the form of $\mathrm{H}_{2} \mathrm{CrO}_{4}$, $\mathrm{HCrO}_{4}^{-}, \mathrm{Cr}_{2} \mathrm{O}_{7}^{2-}$ and $\mathrm{CrO}_{4}^{2-}$ at $\mathrm{pH}$ less than $1, \mathrm{Cr}(\mathrm{VI})$ exists in the form of $\mathrm{H}_{2} \mathrm{CrO}_{4}$, while at $\mathrm{pH}$ between 1 and 6 , $\mathrm{HCrO}_{4}^{-}$and $\mathrm{Cr}_{2} \mathrm{O}_{7}^{2-}$ predominate [44]. In this study, high $\mathrm{pH}$ values were excluded due to precipitation of chromium in alkaline medium [45].
3. Effect of chromium ions concentration: The removal percentage of $\mathrm{Cr}(\mathrm{VI})$ was studied by varying $\mathrm{Cr}$ ions concentrations at constant $\mathrm{CoFe}_{2} \mathrm{O}_{4}$ amount $(0.3 \mathrm{~g})$ and $\mathrm{pH} 3$. Figure $6 \mathrm{c}$ gives the effect of initial concentration of chromium ions on the treatment. As seen, the maximum and minimum removal percent were 89.82 and $58.98 \%$ at the lowest $(0.2 \mathrm{mM})$ and the highest ( $1 \mathrm{mM})$ concentration respectively. Obviously, the removal percent of $\mathrm{Cr}$ ions from solution was found to decrease with increasing the initial concentration of $\mathrm{Cr}$ ions. This observation is in good agreement with a previous study [46]. This is probably due to lack of sufficient surface area to accommodate metal ions from the high concentrated solutions.

\subsection{Treatment of tannery wastewater}

Based on the optimization of treatment conditions, $0.3 \mathrm{~g}$ of nanoferrite was used to treat chromium and other physicochemical parameters at $\mathrm{pH} 3$.

\subsubsection{Total dissolved solids (TDS)}

The TDS values before and after treatment were 18,560 and $1702 \mathrm{mg} / \mathrm{l}$ respectively, giving $90.83 \%$ efficiency. The value of the TDS after treatment was close to the tolerance limits (1500 mg/l) prescribed by SSMO [47]. The presence of high levels of TDS in the tannery wastewater may be due to high salt content and inorganic contents present in the effluent as have been noted by Goel [48]. TDS removal by $\mathrm{CoFe}_{2} \mathrm{O}_{4}$ nanoparticles gave superior results in comparison to the treatment by membrane filtration method, where $68.17 \%$ removal efficiency has been reported [49].

\subsubsection{Biological oxygen demand (BOD)}

The BOD parameters before and after treatment were 2390.7 and $1130.3 \mathrm{mg} / \mathrm{l}$ respectively. The resulting treatment efficiency was $52.7 \%$. The high BOD values may be due to the presence of considerable amounts of organic matter that removed from the skin during the pre-tanning process. Although the BOD value after treatment was still high as compared to permissible disposal limits set by SSMO [47], however, similar results have been reported by the use of the $\mathrm{MgO}$ nanoparticles [50]. In contrast to the traditional methods, which most likely to use the photocatalytic property of the treatment agents, the $\mathrm{CoFe}_{2} \mathrm{O}_{4}$ nanoparticles resulted in less removal efficiency.

\subsubsection{Chemical oxygen demand (COD)}

The COD values before and after treatment were 4120.5 and $2139.6 \mathrm{mg} / \mathrm{l}$ respectively. The resulting treatment 
Fig. 3 a-c SEM images of $\mathrm{CoFe}_{2} \mathrm{O}_{4}$ nanoparticles annealed at 300, 500 and 900 ${ }^{\circ} \mathrm{C}$, d EDX of $\mathrm{CoFe}_{2} \mathrm{O}_{4}$ nanoparticles annealed at $300^{\circ} \mathrm{C}$

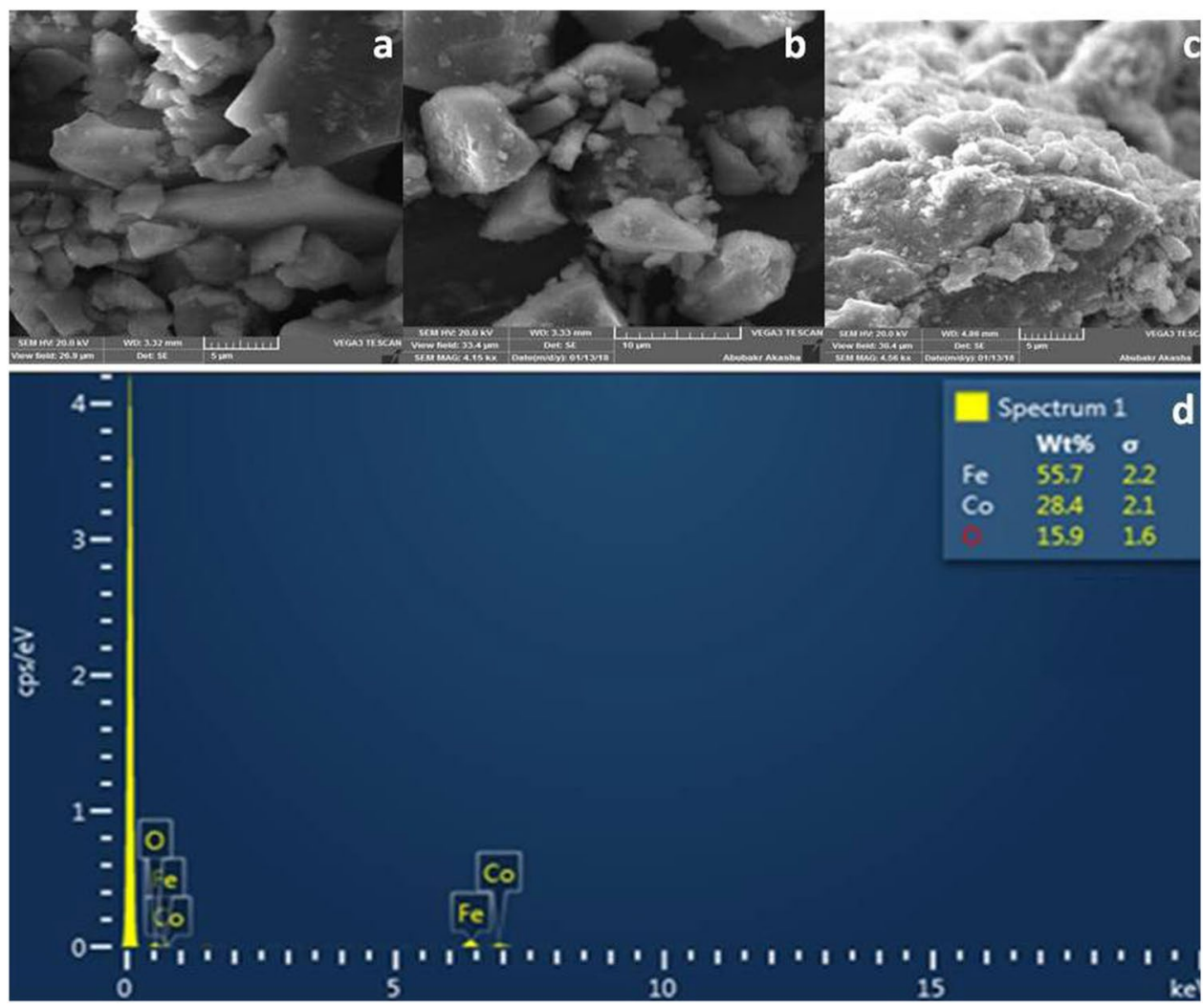

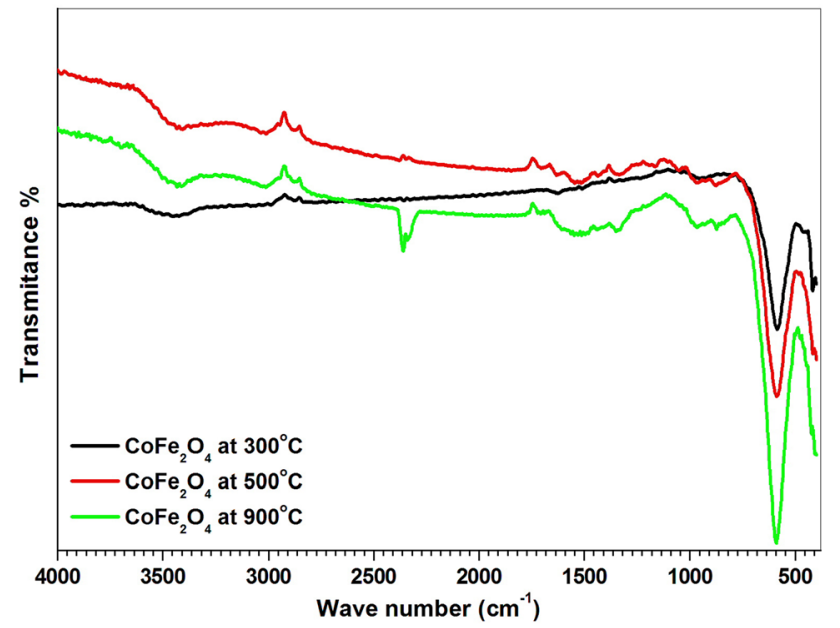

Fig. 4 FTIR of $\mathrm{CoFe}_{2} \mathrm{O}_{4}$ nanoparticles annealed at 300, 500 and $900^{\circ} \mathrm{C}$

efficiency was $48.07 \%$. These values were extremely high compared to recommended standard limits of SSMO (75 mg/l) [47]. This low efficiency may be due to high organic pollutions which are not removed effectively by the nanoferrites. However, Activated Carbon/ $\mathrm{CoFe}_{2} \mathrm{O}_{4}$ nanocomposites have been reported to result in higher removal efficiency [51]. Obviously the nanocomosites have advantages over nanoferrites in the COD

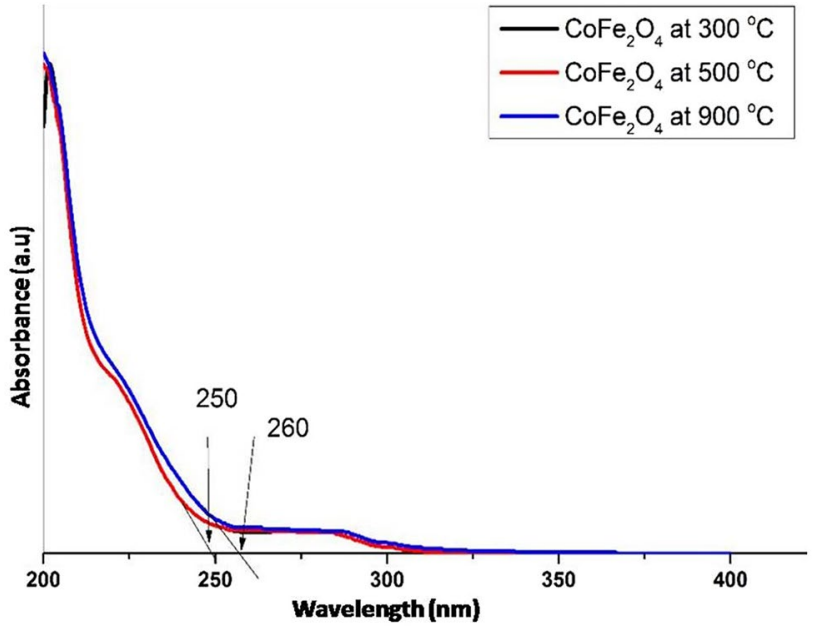

Fig. 5 Absorbance spectra of the $\mathrm{CoFe}_{2} \mathrm{O}_{4}$ nanoferrites annealed at 300,500 and $900^{\circ} \mathrm{C}$

removal as has been reported due to photocatalytic properties of their core shell [51].

\subsubsection{Chromium}

The amount of chromium in the wastewater of Khartoum leather industry before and after treatment were 3.672 and $2.800 \mathrm{mg} / \mathrm{l}$ respectively, resulting in efficiency of 

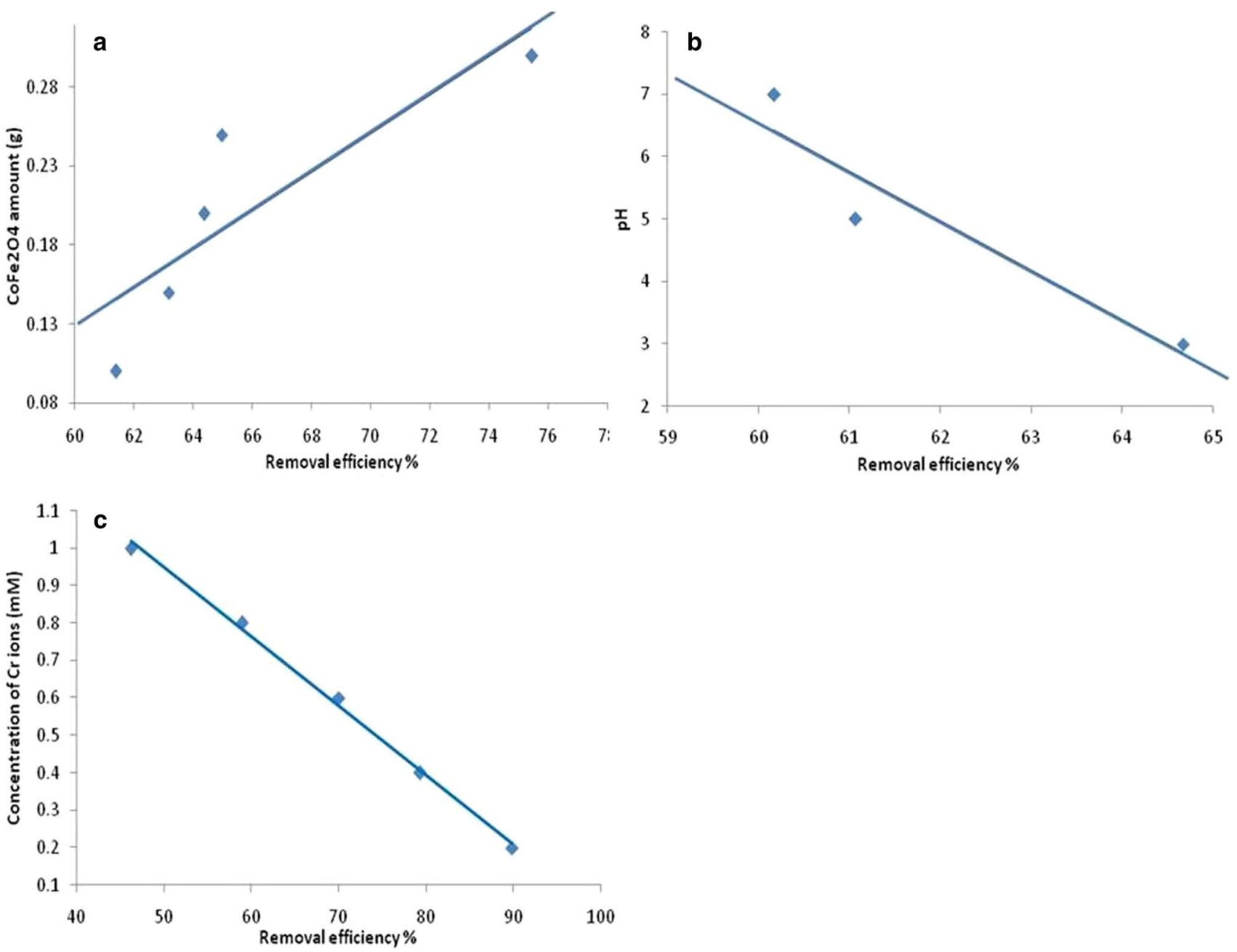

Fig. 6 Effect of different conditions on the removal efficiency of chromium ions by $\mathrm{CoFe}_{2} \mathrm{O}_{4}$ nanoferrites $\mathbf{a}$ amount $\mathbf{b}$ pH $\mathbf{c}$ concentration of chromium ions

$23.75 \%$. Similar results have been reported by Hu et al. using cobalt-ferrite [52]. The remarkable differences in chromium removal efficiency between standard solution and tannery wastewater may be due to blockage of nanoferrite active sites by other contaminants. Low specificity of nanoferrites toward chromium requires pre-treatment of tannery wastewater prior removal.

\section{Conclusion}

The present investigation was carried out to study the suitability of cobalt ferrite nanoparticles for the removal of chromium and other contaminants in the tannery wastewater. The cobalt ferrites nanoparticles were successfully prepared using co-precipitation method by annealing at 300,500 and $900{ }^{\circ} \mathrm{C}$. The synthesized nanoparticles were characterized by XRD, SEM, EDX, FTIR and UV-VIS.
The characterization by these techniques confirmed the formation of nanoparticles. Importantly, the annealing has remarkable effect on the morphologies, sizes and magnetic properties of these nanoparticles. The synthesized nanoparticles were investigated for the treatment of chromium from solutions containing these metal ions to standardize the conditions. Then the nanoparticles were applied for treatment of tannery wastewater. The efficiency of removal of TDS, BOD, COD and chromium were $90.83,52.72,48.07$ and $23.75 \%$ respectively. Thus, the cobalt nanoferrite may be a suitable alternative for the treatment of wastewater and deserve further study.

\section{Compliance with ethical standards}

Conflict of interest The authors declare that they have no conflict of interest. 


\section{References}

1. Shao P, Tian J, Duan X, Yang Y, Shi W, Luo X, Cui F, Luo S, Wang S (2019) Cobalt silicate hydroxide nanosheets in hierarchical hollow architecture with maximized cobalt active site for catalytic oxidation. Chem Eng J 359:79-87. https://doi.org/10.1016/j. cej.2018.11.121

2. Shao P, Tian J, Yang F, Duan X, Gao S, Shi W, Luo X, Cui F, Luo S, Wang $S$ (2018) Catalytic oxidation: identification and regulation of active sites on nanodiamonds: establishing a highly efficient catalytic system for oxidation of organic contaminants. Adv Funct Mater 28(13):1870081. https://doi.org/10.1002/ adfm.201870081

3. Barakat $M(2011)$ New trends in removing heavy metals from industrial wastewater. Arab J Chem 4(4):361-377. https://doi. org/10.1016/j.arabjc.2010.07.019

4. Tripathi A, Ranjan MR (2015) Heavy metal removal from wastewater using low cost adsorbents. J Bioremediat Biodegrad. https ://doi.org/10.4172/2155-6199.1000315

5. Mehdipour S, Vatanpour V, Kariminia HR (2015) Influence of ion interaction on lead removal by a polyamide nanofiltration membrane. Desalination 362:84-92. https://doi.org/10.1016/j.desal .2015.01.030

6. Badruddoza AZM, Shawon ZBZ, Rahman MT, Hao KW, Hidajat K, Uddin MS (2013) lonically modified magnetic nanomaterials for arsenic and chromium removal from water. Chem Eng J 225:607-615. https://doi.org/10.1016/j.cej.2013.03.114

7. Lata S, Samadder S (2016) Removal of arsenic from water using nano adsorbents and challenges: a review. J Environ Manag 166:387-406. https://doi.org/10.1016/j.jenvman.2015.10.039

8. Gupta V, Nayak A (2012) Cadmium removal and recovery from aqueous solutions by novel adsorbents prepared from orange peel and $\mathrm{Fe}_{2} \mathrm{O}_{3}$ nanoparticles. Chem Eng J 180:81-90. https:// doi.org/10.1016/j.cej.2011.11.006

9. Taha MF, Shuib AS, Shaharun MS, Borhan A (2014) Removal of $\mathrm{Ni}(\mathrm{II}), \mathrm{Zn}(\mathrm{II})$ and $\mathrm{Pb}$ (II) ions from single metal aqueous solution using rice husk-based activated carbon. https://doi. org/10.1063/1.4898468

10. Liu T, Wang ZL, Yan X, Zhang B (2014) Removal of mercury(II) and chromium( $(\mathrm{Vl})$ from wastewater using a new and effective composite: pumice-supported nanoscale zero-valent iron. Chem Eng J 245:34-40. https://doi.org/10.1016/j.cej.2014.02.011

11. Sobhanardakani S, Parvizimosaed H, Olyaie E (2013) Heavy metals removal from wastewaters using organic solid wasterice husk. Environ Sci Pollut Res 20(8):5265-5271. https://doi. org/10.1007/s11356-013-1516-1

12. Bauer $\mathrm{R}$ (1999) The photo-fenton reaction and the $\mathrm{TiO}_{2} / \mathrm{UV}$ process for waste water treatment-novel developments. Catal Today 53(1):131-144. https://doi.org/10.1016/s0920 -5861(99)00108-X

13. Wang $Y$, Cheng $R$, Wen $Z$, Zhao $L$ (2011) Synthesis and characterization of single-crystalline $\mathrm{MnFe}_{2} \mathrm{O}_{4}$ ferrite nanocrystals and their possible application in water treatment. Eur J Inorg Chem 2011(19):2942-2947. https://doi.org/10.1002/ejic.201100205

14. Luque R, Baruwati B, Varma RS (2010) Magnetically separable nanoferrite-anchored glutathione: aqueous homocoupling of arylboronic acids under microwave irradiation. Green Chem 12(9):1540. https://doi.org/10.1039/c0gc00083c

15. Willard MA, Kurihara LK, Carpenter EE, Calvin S, Harris VG (2004) Chemically prepared magnetic nanoparticles. ChemInform. https://doi.org/10.1002/chin.200447270

16. Li $P$, Ellsworth $D$, Chang $H$, Janantha $P$, Richardson $D$, Shah $F$ et al (2014) Generation of pure spin currents via spin Seebeck effect in self-biased hexagonal ferrite thin films. Appl Phys Lett 105(24):242412. https://doi.org/10.1063/1.4904479
17. George M, John AM, Nair SS, Joy P, Anantharaman M (2006) Finite size effects on the structural and magnetic properties of sol-gel synthesized $\mathrm{NiFe}_{2} \mathrm{O}_{4}$ powders. J Magn Magn Mater 302(1):190-195. https://doi.org/10.1016/j.jmmm.2005.08.029

18. Bharagava RN, Mishra S (2018) Hexavalent chromium reduction potential of Cellulosimicrobium sp. isolated from common effluent treatment plant of tannery industries. Ecotoxicol Environ Saf 147:102-109. https://doi.org/10.1016/j.ecoenv.2017.08.040

19. Rana A, Kumar V, Thakur OP, Banerjee $A$ (2017) Nano-size analysis through magnetization data for developed $\mathrm{Mn}_{0.5} \mathrm{Zn}_{0.5} \mathrm{X}_{0.2} \mathrm{Fe}_{1.8} \mathrm{O}_{4}$ ( $\mathrm{X}=\mathrm{Fe}, \mathrm{Gd}, \mathrm{La}, \mathrm{Sm}$ ). J Supercond Novel Magn 31(2):463-466. https://doi.org/10.1007/s10948-017-4238-7

20. Nejati K, Zabihi R (2012) Preparation and magnetic properties of nano size nickel ferrite particles using hydrothermal method. Chem Cent J. https://doi.org/10.1186/1752-153x-6-23

21. Singhal S, Namgyal T, Bansal S, Chandra K (2010) Effect of Zn substitution on the magnetic properties of cobalt ferrite nano particles prepared via sol-gel route. J Electromagn Anal Appl 02(06):376-381. https://doi.org/10.4236/jemaa.2010.26049

22. Amiri S, Shokrollahi H (2013) Magnetic and structural properties of RE doped Co-ferrite (REåNd, Eu, and Gd) nano-particles synthesized by co-precipitation. J Magn Magn Mater 345:18-23. https://doi.org/10.1016/j.jmmm.2013.05.030

23. Sutka A, Mezinskis G (2012) Sol-gel auto-combustion synthesis of spinel-type ferrite nanomaterials. Front Mater Sci 6(2):128141. https://doi.org/10.1007/s11706-012-0167-3

24. Su L, Feng J, Zhou X, Ren C, Li H, Chen X (2012) Colorimetric detection of urine glucose based $\mathrm{Znfe}_{2} \mathrm{O}_{4}$ magnetic nanoparticles. Anal Chem 84(13):5753-5758. https://doi.org/10.1021/ ac300939z

25. Guo X, Lu X, Fang X, Mao Y, Wang Z, Chen L, Xu X, Yang H, Liu $Y(2010)$ Lithium storage in hollow spherical $\mathrm{ZnFe}_{2} \mathrm{O}_{4}$ as anode materials for lithium ion batteries. Electrochem Commun 12(6):847-850. https://doi.org/10.1016/j.elecom.2010.04.003

26. Hou $Y$, Zuo F, Dagg A, Feng $P$ (2012) A three-dimensional branched cobalt-doped a- $\mathrm{Fe}_{2} \mathrm{O}_{3}$ nanorod/ $\mathrm{MgFe}_{2} \mathrm{O}_{4}$ heterojunction array as a flexible photoanode for efficient photoelectrochemical water oxidation. Angew Chem 125(4):1286-1290. https://doi.org/10.1002/ange.201207578

27. Sasaki T, Ohara S, Naka T, Vejpravova J, Sechovsky V, Umetsu M, Takami S, Jeyadevan B, Adschiri T (2010) Continuous synthesis of fine $\mathrm{MgFe}_{2} \mathrm{O}_{4}$ nanoparticles by supercritical hydrothermal reaction. J Supercrit Fluids 53(1-3):92-94. https://doi.org/10.1016/j. supflu.2009.11.005

28. Liu F, Laurent S, Roch A, Elst LV, Muller RN (2013) Size-controlled synthesis of $\mathrm{CoFe}_{2} \mathrm{O}_{4}$ nanoparticles potential contrast agent for MRI and investigation on their size-dependent magnetic properties. J Nanomater 2013:1-9. https://doi.org/10.1155/2013/46254 0

29. Kartha K, Pai M, Banerjee A, Pai R, Meena S, Bharadwaj S (2011) Modified surface and bulk properties of Fe-substituted lanthanum titanates enhances catalytic activity for $\mathrm{CO}_{+} \mathrm{N}_{2} \mathrm{O}$ reaction. $J$ Mol Catal A: Chem 335(1-2):158-168. https://doi.org/10.1016/j. molcata.2010.11.028

30. Pradhan P (2012) Effect of Mg and La substitution on electromagnetic properties of $\mathrm{Ni}-\mathrm{Cu}-\mathrm{Zn}$ ferrite. Doctoral dissertation, National Institute of Technology Rourkela. https://manualzz. com/download/18446537

31. Lynda IJC, Durka M, Dinesh A, Manikandan A, Jaganathan SK, Baykal A, Antony SA (2018) Enhanced magneto-optical and photocatalytic properties of ferromagnetic $\mathrm{Mg}_{1-y} \mathrm{Ni}_{\mathrm{y}} \mathrm{Fe}_{2} \mathrm{O}_{4}$ $(0.0 \leq y \leq 1.0)$ spinel nano-ferrites. J Supercond Novel Magn 31(11):3637-3647. https://doi.org/10.1007/s10948-018-4623-x

32. Sharifi I, Shokrollahi H, Doroodmand MM, Safi R (2012) Magnetic and structural studies on $\mathrm{CoFe}_{2} \mathrm{O}_{4}$ nanoparticles synthesized by co-precipitation, normal micelles and reverse micelles 
methods. J Magn Magn Mater 324(10):1854-1861. https://doi. org/10.1016/j.jmmm.2012.01.015

33. Alsabah YA, Alsalhi MS, Elbadawi AA, Mustafa EM (2017) Synthesis and study of the effect of $\mathrm{Ba}^{2+}$ cations substitution with $\mathrm{Sr}^{2+}$ cations on structural and optical properties of $\mathrm{Ba}_{2-x} \mathrm{Sr}_{x} \mathrm{ZnWO}_{6}$ double perovskite oxides $(x=0.00,0.25,0.50,0.75,1.00)$. Materials 10(5):469. https://doi.org/10.3390/ma10050469

34. Vojtěch D, Kubásek J, Šerák J, Novák P (2011) Mechanical and corrosion properties of newly developed biodegradable $\mathrm{Zn}$ based alloys for bone fixation. Acta Biomater 7(9):3515-3522. https://doi.org/10.1016/j.actbio.2011.05.008

35. Rahimi R, Kerdari H, Rabbani M, Shafiee M (2011) Synthesis, characterization and adsorbing properties of hollow $\mathrm{Zn}-\mathrm{Fe}_{2} \mathrm{O}_{4}$ nanospheres on removal of Congo red from aqueous solution. Desalination 280(1-3):412-418. https://doi.org/10.1016/j.desal .2011 .04 .073

36. Ayyappan S, Philip J, Raj B (2009) A facile method to control the size and magnetic properties of $\mathrm{CoFe}_{2} \mathrm{O}_{4}$ nanoparticles. Mater Chem Phys 115(2-3):712-717. https://doi.org/10.1016/j.match emphys.2009.02.005

37. Du D, Yue W, Fan X, Tang K, Yang X (2016) Ultrathin NiO/NiFe $\mathrm{O}_{4}$ nanoplates decorated graphene nanosheets with enhanced lithium storage properties. Electrochim Acta 194:17-25. https ://doi.org/10.1016/j.electacta.2016.02.085

38. Catherine Y, Turban G (1980) Infrared absorption of hydrogenated amorphous $\mathrm{Si}-\mathrm{C}$ and Ge-C films. Thin Solid Films 70(1):101-104. https://doi.org/10.1016/0040-6090(80)90416-2

39. Rodríguez-Rodríguez AA, Martínez-Montemayor S, LeyvaPorras CC, Longoria-Rodríguez FE, Martínez-Guerra E, SánchezDomínguez $\mathrm{M}$ (2017) $\mathrm{CoFe}_{2} \mathrm{O}_{4}-\mathrm{TiO}_{2}$ hybrid nanomaterials: synthesis approaches based on the oil-in-water microemulsion reaction method. J Nanomater 2017:1-15. https://doi. org/10.1155/2017/2367856

40. Alsabah YA, Alsalhi MS, Elbadawi AA, Mustafa EM (2017) Influence of $\mathrm{Zn}^{2+}$ and $\mathrm{Ni}^{2+}$ cations on the structural and optical properties of $\mathrm{Ba}_{2} \mathrm{Zn}_{1-x} \mathrm{Ni}_{x} \mathrm{WO}_{6}(0 \leq \mathrm{x} \leq 1)$ tungsten double perovskites. J Alloys Compd 701:797-805. https://doi.org/10.1016/j. jallcom.2017.01.203

41. Dargahi A, Gholestanifar H, Darvishi P, Karami A, Hasan SH, Poormohammadi A, Behzadnia A (2016) An investigation and comparison of removing heavy metals (lead and chromium) from aqueous solutions using magnesium oxide nanoparticles. Pol J Environ Stud 25(2):557-562. https://doi.org/10.15244/pjoes 160281

42. Sharma R, Komal KV, Bansal S, Singhal S (2017) Boosting the catalytic performance of pristine $\mathrm{CoFe}_{2} \mathrm{O}_{4}$ with yttrium $\left(\mathrm{Y}_{3}\right)$ inclusion in the spinel structure. Mater Res Bull 90:94-103. https ://doi.org/10.1016/j.materresbull.2017.01.049

43. Simeonidis K, Mourdikoudis S, Kaprara E, Mitrakas M, Polavarapu $L$ (2016) Inorganic engineered nanoparticles in drinking water treatment: a critical review. Environ Sci Water Res Technol 2(1):43-70. https://doi.org/10.1039/c5ew00152h

44. Wu Y, Li B, Feng S, Mi X, Jiang J (2009) Adsorption of $\mathrm{Cr}(\mathrm{VI})$ and As(III) on coaly activated carbon in single and binary systems. Desalination 249(3):1067-1073. https://doi.org/10.1016/j.desal 2009.06.049

45. Xie LP, Fu FL, Tang B (2012) Removal of chromium from CrEDTA synthetic wastewater using advanced fenton-hydroxide precipitation process. Adv Mater Res 550-553:2005-2008. https://doi. org/10.4028/www.scientific.net/amr.550-553.2005

46. Unnithan MR, Anirudhan TS (2001) The kinetics and thermodynamics of sorption of chromium(VI) onto the iron(III) complex of a carboxylated polyacrylamide-grafted sawdust. Ind Eng Chem Res 40(12):2693-2701. https://doi.org/10.1021/ie0009740

47. Sudanese Standards and Metrological Organization (SSMO) (2002) Sudanese wastewater standards. Issued in Feb 2002

48. Goel PK (2006) Water pollution: causes, effects and control. New Age International, New Delhi

49. Noorjahan CNC (2011) Physicochemical characteristics, identification of bacteria and biodegradation of industrial effluent. Indian J Appl Res 4(8):678-682. https://doi.org/10.15373/22495 55x/august2014/178

50. Oladipo AA, Adeleye OJ, Oladipo AS, Aleshinloye AO (2017) Bioderived $\mathrm{MgO}$ nanopowders for $\mathrm{BOD}$ and $\mathrm{COD}$ reduction from tannery wastewater. J Water Process Eng 16:142-148. https:// doi.org/10.1016/j.jwpe.2017.01.003

51. Heidari $M$, Varma $R$, Ahmadian $M$, Pourkhosravani $M$, Asadzadeh S, Karimi P, Khatami M (2019) Photo-fenton like catalyst system: activated carbon/CoFe $\mathrm{O}_{4}$ nanocomposite for reactive dye removal from textile wastewater. Appl Sci 9(5):963. https://doi. org/10.3390/app9050963

52. Hu J, Lo I, Chen G (2007) Comparative study of various magnetic nanoparticles for $\mathrm{Cr}(\mathrm{VI})$ removal. Sep Purif Technol 56(3):249256. https://doi.org/10.1016/j.seppur.2007.02.009

Publisher's Note Springer Nature remains neutral with regard to jurisdictional claims in published maps and institutional affiliations. 